\title{
EVALUASI FEEDING MANAGEMENT : SUBSTITUSI PAKAN ALAMI OLEH PAKAN BUATAN DENGAN PENAMBAHAN PROBIOTIK TERHADAP PERFORMA TUMBUH LARVA IKAN LELE Clarias $\mathrm{sp.}$
}

\author{
Firsty Rahmatia ${ }^{1)}$ \\ ${ }^{1)}$ Fakultas Perikanan dan Ilmu Kelautan, Universitas Satya Negara Indonesia
}

\begin{abstract}
Abstrak
Pembenihan merupakan bagian penting dari kegiatan budidaya ikan karena bertujuan untuk memenuhi kebutuhan benih dengan kuantitas dan kualitas yang baik pada saat dibutuhkan. Salah satu komoditas akuakultur yang sangat digemari adalah ikan lele. Benih ikan lele diperoleh dari hasil pemeliharaan larva sampai ukuran benih siap tebar. Pemeliharaan larva merupakan fase kritis karena terkait masalah pakan. Para pembudidaya ikan lele umumnya menjatuhkan pilihan pada cacing sutera yang lebih banyak mengandalkan hasil tangkapan dari alam. Salah satu solusi adalah mengganti (substitusi) cacing sebagai pakan alami dengan pakan buatan yang ditambah probiotik. Perlakuan substitusi yang dilakukan pada penelitian ini adalah $A=0 \%$ (kontrol), $B=25 \%$, $C=50 \%, D=75 \%$ dan E=100\%. Hasil penelitian menunjukkan bahwa substitusi pakan alami oleh pakan buatan yang ditambah probiotik memberikan pengaruh yang nyata terhadap performa tumbuh larva Ikan Lele. Parameter yang berpengaruh nyata adalah panjang rataan dan kelangsungan hidup larva. Panjang rataan yang berbeda nyata dengan kontrol ditunjukkan oleh perlakuan B sebesar 2,94 cm, perlakuan C sebesar 2,92 cm, dan D sebesar 2,73 cm. Kelangsungan hidup terbaik ditunjukkan oleh perlakuan C yaitu sebesar 94\%. Secara keseluruhan kinerja pertumbuhan, perlakuan terbaik ditunjukkan oleh perlakuan C (substitusi pakan alami oleh pakan buatan+probiotik 50\%).
\end{abstract}

Kata Kunci: Larva Lele, Substitusi Pakan Buatan, Probiotik

\begin{abstract}
Hatcheries are an important part of the activities of fish farming as it aims to fullfill the needs of the seed with the good quantity and quality. One of the aquaculture commodities that very popular is the catfish. Catfish seed obtained from the larva to the size of the seed that ready for stocking. Maintenance of larvae is a critical phase for feed-related issues. The catfish farmers are generally settled on silk worms that rely more on catches from nature. One solution is to replace (substitution) worm as a natural food with artificial feed plus probiotics. Substitution treatment performed in this study are $A=0 \%$ (control), $B=$ $25 \%, C=50 \% \mathrm{D}=75 \%$ and $E=100 \%$. The results showed that the substitution of natural feed by artificial feed plus probiotic significantly effect on the performance of growing larvae Catfish. Parameters that significantly is the average length and larval survival. The average length is significantly different from the control shown by the treatment of $B$ of 2.94 $\mathrm{cm}, 2.92 \mathrm{~cm}$ for treatment $C$, and $D$ of $2.73 \mathrm{~cm}$. Best survival demonstrated by treatment of $C$ is equal to 94\%. Overall growth performance, the best treatment is indicated by treatment of $C$ (natural feed substitution by artificial feed probiotic $+50 \%$ ).
\end{abstract}

Keywords: Catfish Larva, Feed Substitution, Probiotic 


\section{PENDAHULUAN}

Budidaya ikan adalah upaya campur tangan manusia dalam menumbuhkembangkan ikan dalam lingkungan yang terkontrol. Kegiatan budidaya secara garis besar mencakup pembenihan, pendederan, dan pembesaran. Pembenihan merupakan bagian penting dari kegiatan budidaya ikan karena bertujuan untuk memenuhi kebutuhan benih dengan kuantitas dan kualitas yang baik pada saat dibutuhkan. Salah satu komoditas akuakultur yang sangat digemari adalah ikan lele. Benih ikan lele diperoleh dari hasil pemeliharaan larva sampai ukuran benih siap tebar. Pemeliharaan larva merupakan fase kritis, karena pada tahap ini, ikan mengalami peralihan dari fase endogenous feeding ke fase exogenous feeding. Peralihan fase tersebut dialami oleh ikan lele pada hari ketiga dan keempat setelah menetas. Pada fase ini, pakan yang tersedia harus dapat memenuhi kebutuhan pertumbuhan larva, jika tidak maka akan menghambat pertumbuhan bahkan mengakibatkan kematian.

Kualitas fisik pakan seperti ukuran pakan menjadi penting untuk diperhatikan. Ukuran pakan yang diberikan harus lebih kecil daripada ukuran bukaan mulut ikan sehingga akan direspon positif dengan memangsa pakan tersebut (Halver, 1989). Para pembudidaya ikan lele umumnya menjatuhkan pilihan pada cacing sutera. Namun, budidaya cacing sutera sampai saat ini masih belum intens dikembangkan, sehingga pemenuhan akan kebutuhan cacing sutera lebih banyak mengandalkan hasil tangkapan dari alam. Sementara itu, ketersediaan cacing sutera di alam tidak terpenuhi sepanjang tahun. Pada musim penghujan, biasanya ketersediaanya akan menurun karena terbawa arus deras akibat curah hujan yang cukup tinggi (Fajri dan Hutabarat, 2014). Harga cacing pun akan mengalami kenaikan hingga Rp. 3000 dari harga biasa dan akan mengakibatkan naiknya biaya produksi. Kendala ini juga dialami dalam kegiatan pemeliharaan larva lele hasil pembenihan yang dilakukan di Laboratorium Akuakultur, Universitas Satya Negara Indonesia.

Salah satu upaya untuk keluar dari masalah ini adalah dengan mengganti (substitusi) cacing sebagai pakan alami dengan pakan buatan. Namun, pakan buatan memiliki kelemahan yaitu; tidak adanya enzim yang dibutuhkan larva untuk membantu kecernaan pakan buatan tersebut. Penelitian Nurhayati (2014) menunjukkan bahwa ketika larva diberi pakan buatan saja, kelangsungan hidupnya lebih rendah daripada perlakuan pemberian cacing sutera saja dan kombinasi pakan buatan dan cacing sutera. Peningkatan kecernaan terhadap pakan buatan dilakukan dengan menambahkan probiotik sebagai penghasil enzim. Probiotik mempengaruhi inang dengan cara meningkatkan keseimbangan usus untuk meningkatkan kecernaan (Verschuere et al., 2000 dalam Anggrainy, 2015)

Penelitian ini perlu dilakukan untuk mengevaluasi dan modifikasi perlakuan berdasarkan penelitian-penelitian sebelumnya. Melalui penelitian ini diharapkan akan memberikan hasil yang baik sehingga menjadi acuan dalam manajemen pemberian pakan larva lele di Laboratorium Akuakultur, Universitas Satya negara Indonesia agar larva yang dihasilkan dapat memberikan sintasan dan pertumbuhan yang maksimal.

Kesulitan mencari pakan yang tepat intuk larva ikan lele menjadi salah satu kendala bagi pembenihan ikan termasuk kegiatan pembenihan di Laboratorium Akuakultur, Universitas Satya Negara Indonesia. Peneliti mencoba melihat salah satu kendala yaitu tidak mencukupinya ketersediaan pakan alami terutama cacing sutra untuk memenuhi setiap kebutuhan. Salah satu solusi yang ditawarkan adalah dengan mengganti pakan alami dengan pakan buatan. Akan tetapi, kekurangan pakan buatan bagi larva adalah masih belum sempurnanya organ pencernaan sehingga sekresi enzim pencernaan belum memadai. Pemberian probiotik sebagai campuran pakan buatan diharapkan akan mampu meningkatkan kecernaan pakan buatan oleh larva ikan, sehingga ketergantungan larva akan 
pakan alami berupa cacing sutra dapat diminimalisir dan performa pertumbuhan larva juga semakin baik.

Penelitian ini bertujuan untuk mengevaluasi substitusi pakan alami oleh pakan buatan dengan penambahan probiotik terhadap performa tumbuh larva ikan lele. Hasil dari penelitian ini diharapkan mampu memberikan kontribusi terhadap peningkatan performa tumbuh dan sintasan larva ikan lele. Selain itu, hasil penelitian juga dapat menjadi acuan (Standar Operasional Prosedur) bagi manajemen pemberian pakan ikan lele hasil pembenihan Laboratorium Akuakultur, Universitas Satya Negara Indonesia.

\section{METODOLOGI}

\section{Waktu dan Tempat Kegiatan}

Penelitian dan analisis dilaksanakan selama 3 (tiga) bulan dan dilakukan di Laboratorium Akuakultur, Universitas Satya Negara Indonesia.

\section{Alat dan Bahan}

Alat yang digunakan selama penelitian adalah peralatan pemeliharaan meliputi akuarium/toples kecil dengan volume $5 \mathrm{~L}$ sejumlah 20 unit yang dilengkapi dengan sistem aerasi dan heater/temostat. Peralatan sampling meliputi timbangan, penggaris, tissue, kanebo, kain lap, gunting, pinset, alat dokumentasi dan alat tulis.

Bahan yang digunakan untuk penelitian adalah cacing sutera, pakan komersil untuk larva, probiotik dengan merk dagang E4, larva ikan lele Clarias sp., serta methilene blue.

\section{Kegiatan Penelitian}

Larva ikan lele umur 3 hari ditebar ke dalam toples bervolume 5 L dengan kepadatan 25 ekor/L. Sebelum dilakukan penebaran, dilakukan persiapan wadah dan media terlebih dahulu. Air telah diendapkan dalam wadah selama 3 hari. Larva dipelihara sampai berumur 15 hari. Selama masa pemeliharaan, larva diberi pakan sesuai dengan perlakuannya. Pergantian air dilakukan secara periodik guna menjaga kualitas air agar tetap optimum bagi pemeliharaan larva. Pergantian air mulai dilakukan pada saat larva berumur 5 hari, yaitu bersamaan dengan pemberian pakan pertama. Penyiponan dan pergantian air secara rutin selanjutnya dilakukan satu kali sehari sebanyak $10 \%$ dari total volume air yaitu pada jam 09.00 WIB. Pengecekan suhu dilakukan setiap hari pada pukul 12.00 dan 22.00 WIB. Suhu selama penelitian berkisar antara $27^{\circ} \mathrm{C}-31^{\circ} \mathrm{C}$.

Perlakuan substitusi pakan alami berupa cacing sutera oleh pakan buatan yang ditambahkan probiotik dilakukan dengan 5 perlakuan dan 4 ulangan. Adapun perlakuan tersaji dalam tabel di bawah ini :

Tabel 1. Perlakuan Penelitian

\begin{tabular}{|c|c|c|c|c|}
\hline \multicolumn{5}{|c|}{ Substitusi cacing sutera oleh pakan buatan (\%) } \\
\hline A & B & C & D & E \\
\hline 0 & 25 & 50 & 75 & 100 \\
\hline
\end{tabular}

Keterangan :

A $=$ Pemberian cacing sutera $100 \%$

$\mathrm{B}=$ Pemberian cacing sutera $75 \%$ dan pakan buatan+probiotik $25 \%$

$\mathrm{C}=$ Pemberian cacing sutera $50 \%$ dan pakan buatan+probiotik $50 \%$

$\mathrm{D}=$ Pemberian cacing sutera $25 \%$ dan pakan buatan+probiotik $75 \%$

$\mathrm{E}=$ Pemberian pakan buatan+probiotik $100 \%$ 
Manajemen pemberian pakan larva pada saat umur dua dan tiga hari (D2-D3), tidak diberi pakan karena masih mengandung kuning telur. Pada umur D4 larva sampai dengan D15 diberikan pakan sesuai dengan perlakuan dengan frekuensi 4 kali sehari, yaitu pukul 07.00-08.00 WIB, 12.00-13.00 WIB, 17.00-18.00 WIB dan 22.00-23.00 WIB. Pakan alami diberikan secara ad libitum dan pakan buatan diberikan dengan feeding rate $10 \%$ dari bobot biomassa. Probiotik diberikan pada saat pemberian pakan pukul 07.00-08.00 WIB dengan cara mencampurkan cairan probiotik $(2 \mathrm{~mL})$ dengan pakan buatan yang akan diberikan pada ikan.

Pada hari ke-17 (D17) dilakukan sampling akhir atau pemanenan setelah dilakukan pemuasaan selama 24 jam pada hari ke-16 (D16). Panen dilakukan pada pukul 07.00 WIB. Jumlah larva yang hidup pada akhir pemeliharaan dihitung untuk mengetahui sintasan atau kelangsungan hidup larva. Panjang larva dihitung dengan mengambil sampel sebanyak 5 ekor larva dari setiap wadah pemeliharaan. Bobot larva ditimbang untuk mendapatkan bobot biomassa.

\section{Panjang Rataan Benih Ikan Lele}

Panjang rata-rata merupakan panjang total yang diukur dari ujung kepala sampai dengan ujung ekor menggunakan jangka sorong dibandingkan dengan jumlah benih.

Panjang rataan $=\frac{\text { Panjang total }(\mathrm{cm})}{\text { Jumlah ikan }(\text { ekor })}$

\section{Bobot Rataan Benih Ikan Lele}

Bobot rata-rata merupakan bobot total biomassa yang diukur menggunakan timbangan digital dibandingkan dengan jumlah benih.

Bobot rataan $=\frac{\text { Biomassa }(\mathrm{g})}{\text { Jumlah ikan (ekor) }}$

Kelangsungan Hidup/Sintasan

Kelangsungan hidup (\%) $=\frac{\text { Jumlah ikan akhir (ekor) }}{\text { Jumlah ikan awal (ekor) }} \times 100 \%$

\section{Koefisien Keragaman Panjang \\ Koefisien keragaman panjang $(\%)=\frac{\text { Standar deviasi }}{\text { Panjang rata }- \text { rata }} \times 100 \%$}

Analisis Usaha

Analisis usaha yang dihitung berupa penjualan ikan akhir berdasarkan ukuran dan biaya pakan yang dikeluarkan selama pemeliharaan, sehingga diperoleh selisih penjualan ikan dengan biaya pakan.

\section{Analisis Data}

Penelitian menggunakan Rancangan Acak Lengkap (RAL) dengan 5 perlakuan dan 4 ulangan. Analisis data menggunakan SPSS, apabila terdapat perbedaan yang nyata maka diuji lanjut menggunakan uji Duncan. Parameter yang diuji statistik adalah parameter 
kuantitatif meliputi : panjang rataan, bobot rataan, sintasan, protein efisiensi rasio dan koefisien keragaman panjang.

Model linear Rancangan Acak Lengkap (RAL) yang digunakan adalah:

$$
Y_{i j}=\mu+\tau_{i}+\varepsilon_{i j}
$$

\section{Keterangan:}

$\mathrm{i} \quad=1,2, \ldots, \mathrm{t}$ (perlakuan)

$\mathrm{j} \quad=1,2, \ldots, \mathrm{r}$ (ulangan)

$\mathrm{Y}_{\mathrm{ij}} \quad=$ Pengamatan pada perlakuan ke-i dan ulangan ke-j

$\mu \quad=$ Rataan umum

$\tau_{\mathrm{I}} \quad=$ Pengaruh perlakuan ke-i

$\varepsilon_{\mathrm{ij}} \quad=$ Pengaruh acak pada perlakuan ke-i ulangan ke-j

Tabel 2. Tabel Desain Penelitian (5 perlakuan, 4 ulangan)

\begin{tabular}{|c|c|c|c|c|c|}
\hline \multirow{2}{*}{ Ulangan } & \multicolumn{5}{|c|}{ Perlakuan } \\
\cline { 2 - 6 } & $0 \%$ (Kontrol) & $25 \%$ & $50 \%$ & $75 \%$ & $100 \%$ \\
\hline 1 & $\mathrm{~A} 1$ & $\mathrm{~B} 1$ & $\mathrm{C} 1$ & $\mathrm{D} 1$ & E1 \\
\hline 2 & $\mathrm{~A} 2$ & $\mathrm{~B} 2$ & $\mathrm{C} 2$ & $\mathrm{D} 2$ & E2 \\
\hline 3 & $\mathrm{~A} 3$ & $\mathrm{~B} 3$ & $\mathrm{C} 3$ & $\mathrm{D} 3$ & E3 \\
\hline 4 & $\mathrm{~A} 4$ & $\mathrm{~B} 4$ & $\mathrm{C} 4$ & $\mathrm{D} 4$ & E4 \\
\hline
\end{tabular}

\section{HASIL DAN PEMBAHASAN}

Parameter utama yang diamati pada penelitian ini adalah performa pertumbuhan larva. Performa pertumbuhan yang pertama dapat dilihat dari hasil panjang rataan larva dari setiap perlakuan pada akhir pemeliharaan. Berdasarkan hasil uji statistik (Lampiran), substitusi cacing oleh pakan buatan yang ditambah probiotik memperikan pengaruh yang berbeda nyata terhadap panjang rataan larva Ikan Lele $(\mathrm{P}<0.05)$. 


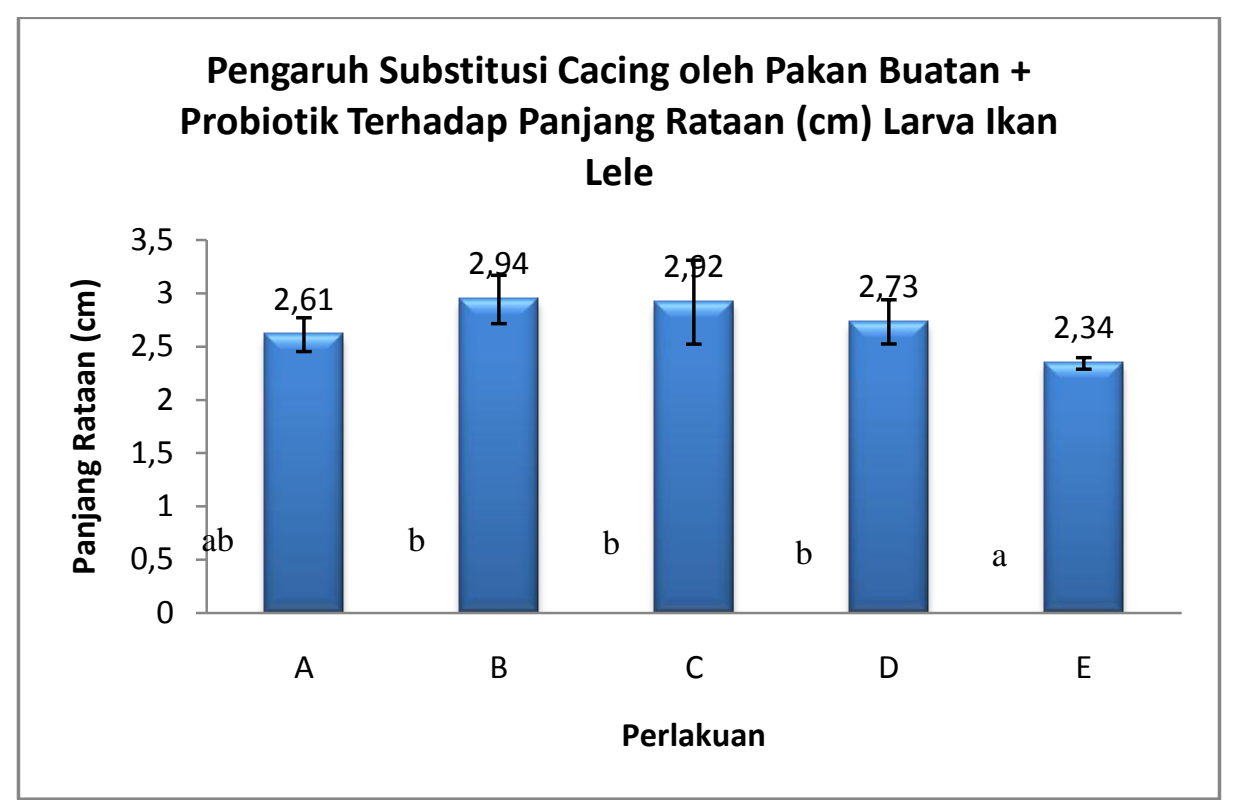

Gambar 1. Grafik panjang rataan larva Ikan Lele (Huruf yang berbeda pada grafik menunjukkan perbedaan yang nyata, $\mathrm{P}<0.05)$.

Berdasarkan grafik di atas, hasil uji statistik menunjukkan bahwa perlakuan B (substitusi 25\% pakan buatan + probiotik), C (substitusi 50\% pakan buatan + probiotik), dan $\mathrm{D}$ (substitusi $75 \%$ pakan buatan + probiotik) memberikan nilai panjang rataan lebih baik daripada perlakuan kontrol (A) dan perlakuan E (100\% pakan buatan). Panjang rataan terendah adalah pada perlakuan E. Pertumbuhan ikan ditentukan oleh komposisi pakan yang dikonsumsinya terutama protein. Ikan makan untuk memenuhi kebutuhan energi dan untuk pertumbuhan. Adapun komponen nutrien yang digunakan untuk tumbuh adalah protein, karena memegang fungsi sebagai pembentuk jaringan-jaringan baru dan sebagai zat pembangun (Halver, 1989). Hal senada dikemukakan pula oleh Subandiyono dan Elfitrasari (2013) pertumbuhan ikan dipengaruhi oleh protein yang didapat dari pakan. Protein yang diperoleh pakan akan digunakan untuk pertumbuhan dan perbaikan jaringan. Protein dengan kecernaan yang tinggi dapat dimanfaatkan oleh tubuh dengan tinggi sehingga dapat menghasilkan pertumbuhan yang optimal.

Dalam penelitian ini perlakuan B, C, dan D diduga sudah memiliki komposisi protein yang baik untuk pertumbuhan larva ikan Lele yang dibuktikan dengan pertumbuhan panjang yang lebih baik. Perlakuan E yang menggunakan pakan buatan $100 \%$ memberikan pertumbuhan panjang terendah diduga disebabkan oleh kemampuan larva yang belum mampu maksimal mengolah pakan buatan untuk pemenuhan energi dan pertumbuhannya. Hal ini terkait dengan sistem pencernaan larva yang belum lengkap dan ketersediaan enzim percernaan yang belum maksimal (Kamler, 1992). Sehingga ketika larva lele pada umur 415 hari belum mampu mentolerir pakan buatan pada level tertentu, dalam penelitian ini adalah pakan buatan $100 \%$ (meskipun telah dicampurkan dengan probiotik) dan sebaiknya tetap diberi asupan pakan alami. Pemberian probiotik sendiri adalah salah satu upaya untuk menambah bakteri penghasil enzim pencernaan ke dalam sistem pencernaan larva agar kemampuan cernanya meningkat sehingga dapat memanfaatkan pakan buatan dengan maksimal. Probiotik merupakan suplemen pakan yang menguntungkan mempengaruhi inang dengan cara meningkatkan keseimbangan usus untuk meningkatkan kecernaan (Verschuere et al. 2000). Adapun probiotik yang digunakan pada penelitian ini adalah bakteri dari genus Bacillus. Menurut Aslamsyah et al. (2009), salah satu mikroba yang 
menguntungkan yang terdapat dalam pencernaan addalah Bacillus sp. yang berperan dalam meningkatkan kecernaan nutrien pakan melalui enzim eksogen yang disekresikan.

Selain panjang rataan, parameter lain yang diamati adalah bobot rataan dan koefisien keragaman panjang. Berdasarkan uji statistik (Lampiran), substitusi pakn alami oleh pakan buatan yang ditambahkan dengan probiotik tidak berpengaruh nyata terhadap bobot rataan dan koefisien keragaman panjang larva Ikan Lele $(P>0.05)$. Grafik hasil penelitian adalah sebagai berikut.

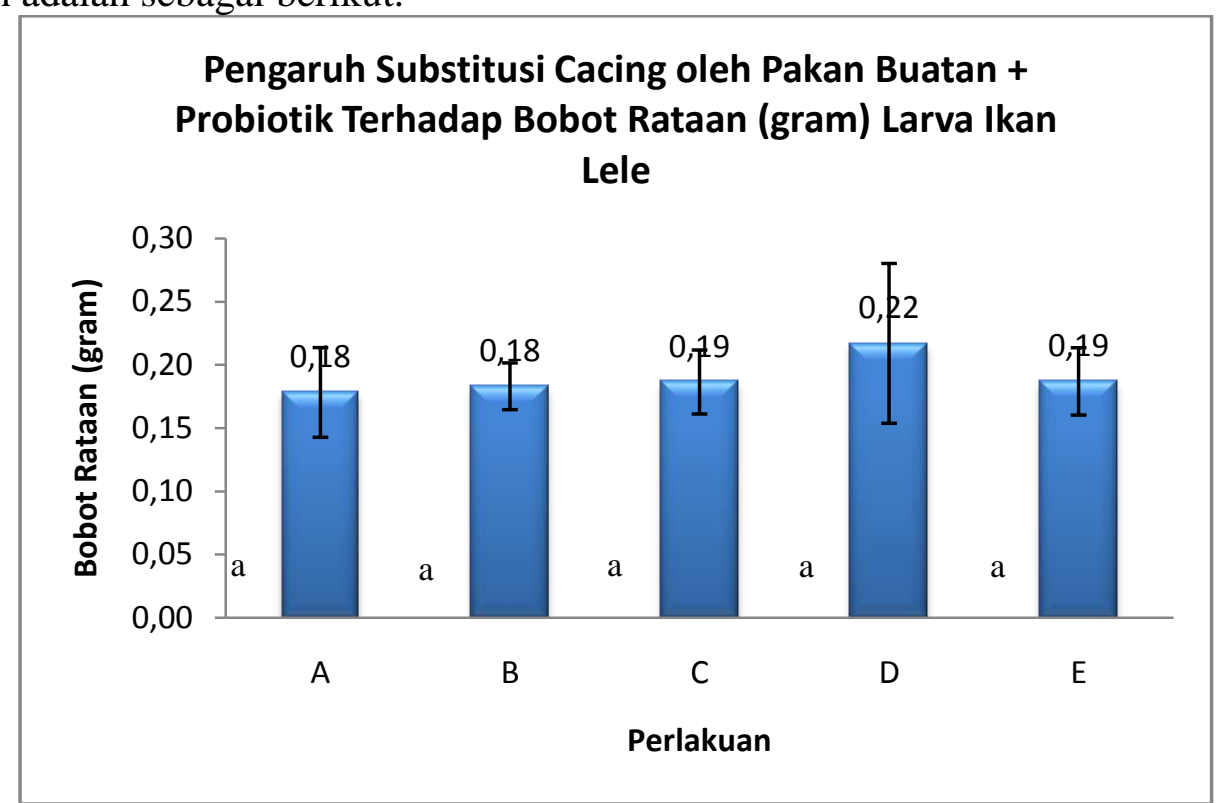

Gambar 2. Grafik bobot rataan larva Ikan Lele (Huruf yang sama pada grafik menunjukkan tidak terdapat perbedaan yang nyata, $\mathrm{P}>0.05$ )

Grafik di atas menunjukkan pola bobot rataan dimana yang tertinggi ditunjukkan oleh perlakuan D (substitusi pakan buatan+probiotik 75\%) dan terendah adalah perlakuan A (kontrol, cacing 100\%) dan B (substitusi pakan buatan +probiotik 25\%). Hasil tersebut menggambarkan bahwa larva mampu memanfaatkan pakan buatan yang ditambah probiotik sampai level tertentu sama baiknya dengan pemanfaatan pakan alami untuk pertumbuhannya. Parameter koefisien keragaman panjang juga menunjukkan hasil yang serupa dengan bobot rataan. Tidak ada perbedaan keragaman panjang yang nyata $(\mathrm{P}>0.05)$ yang dihasilkan oleh larva yang diberi pakan perlakuan dengan persentase substitusi pakan buatan+probiotik yang berbeda. Meskipun diberikan pakan buatan, keragaman panjang larva yang dihasilkan tidak berbeda dengan larva yang diberi pakan alami berupa cacing sutera, dengan kata lain panjang larva dari semua perlakuan mendekati seragam. 


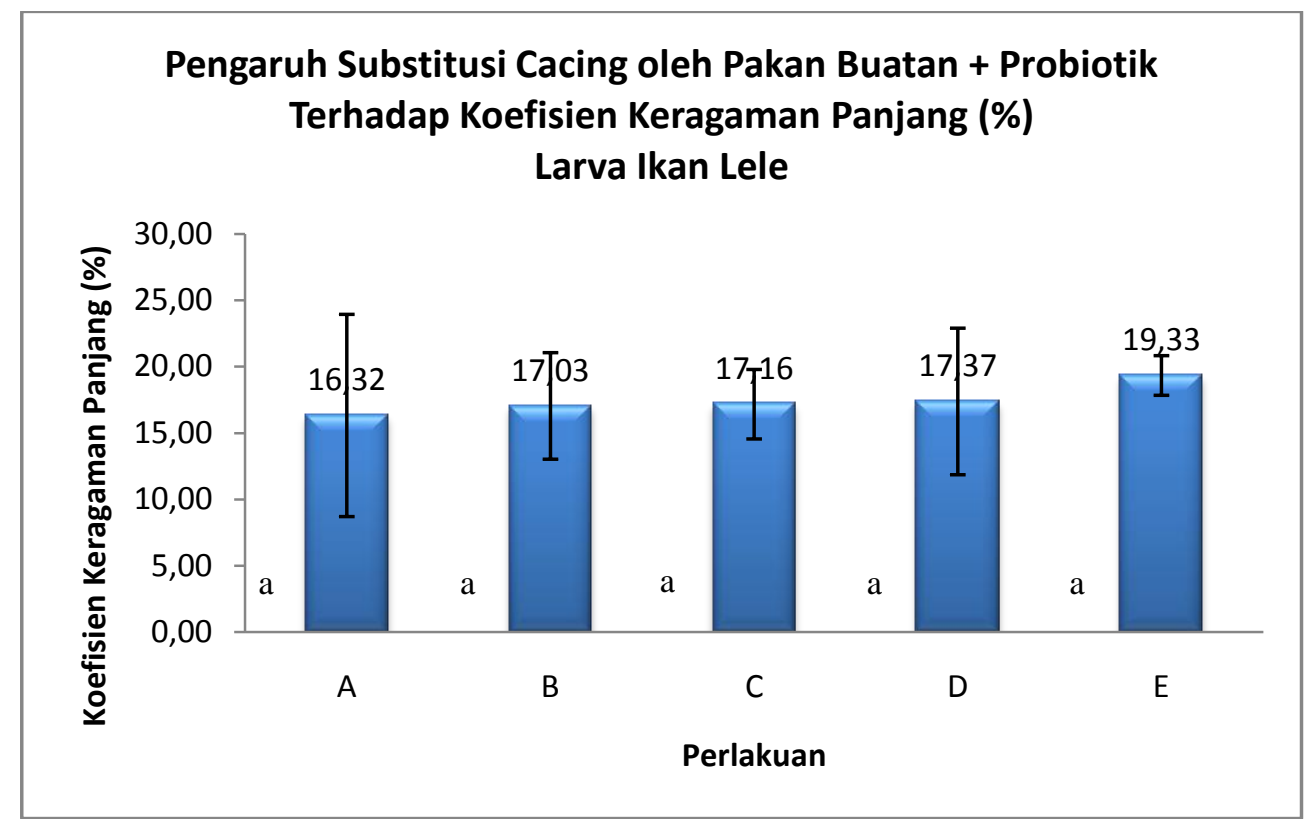

Gambar 3. Grafik koefisien keragaman panjang larva Ikan Lele (Huruf yang sama pada grafik menunjukkan tidak terdapat perbedaan yang nyata, $\mathrm{P}>0.05$ ).

Parameter selanjutnya adalah sintasan atau kelangsungan hidup larva. Berdasarkan uji statistik (Lampiran 3), substitusi pakan alami oleh pakan buatan+probiotik memberikan pengaruh yang nyata terhadap sintasan atau kelangsungan hidup larva Ikan Lele $(\mathrm{P}<0.05)$.

\section{Pengaruh Substitusi Cacing oleh Pakan Buatan + Probiotik \\ Terhadap Kelangsungan Hidup (\%) \\ Larva Ikan Lele}

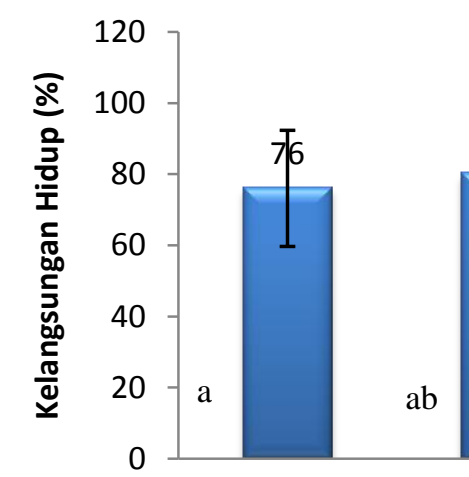

A

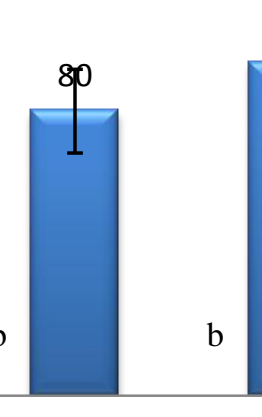

B

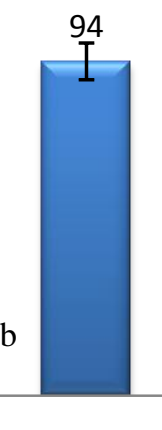

C

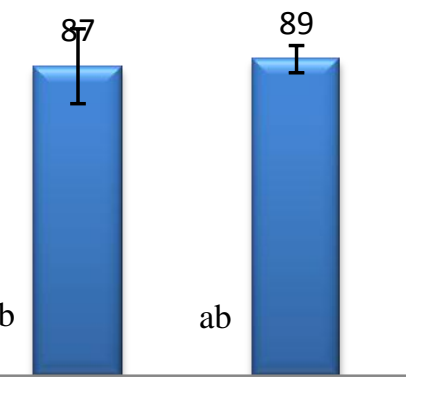

D

Perlakuan

Gambar 4. Grafik kelangsungan hidup larva Ikan Lele (Huruf yang tidak sama pada grafik menunjukkan perbedaan yang nyata, $\mathrm{P}<0.05)$.

Kelangsungan hidup tertinggi dihasilkan oleh perlakuan $\mathrm{C}$ (substitusi pakan buatan+probiotik 50\%). Perlakuan ini berbeda nyata dengan perkakuan kontrol (A) yang tidak diberi pakan buatan sama sekali. Hasil ini sama dengan hasil penelitian Nurhayati (2014) dimana kelangsungan hidup larva Ikan Lele yang diberi kombinasi pakan buatan dan cacing sutera dengan perbandingan 1:1 memberikan persentase tertinggi. Berdasarkan pengamatan di lapangan larva yang diberi pakan hanya cacing sutera lebih agresif daripada 
larva yang diberikan pakan buatan, sehingga pada perlakuan A diduga lebih banyak terjadi kanibalisme daripada perlakuan yang lain, hal ini lah yang menyebabkan kelangsungan hidupnya relatif lebih rendah. Kemudian kompetisi dalam proses mengambil makanan cacing sutera lebih tinggi karena sifat cacing yang mengumpul di satu tempat. Sementara, apabila diberi pakan buatan yang berbentuk serbuk, pakan akan menyebar di permukaan air sehingga larva dapat mengakses pakan di seluruh permukaan media.

Analisis usaha dihitung berdasarkan berdasarkan selisih dari pengeluaran untuk pakan dan pendapatan dari penjualan benih (dengan asumsi seluruh benih terjual), keuntungan terbesar diperoleh dari perlakuan $\mathrm{C}$ (substitusi pakan buatan+probiotik 50\%) dikarenakan jumlah benih yang dijual jumlahnya lebih besar (kelangsungan hidup tertinggi). Biaya pengeluaran pakan terendah memang dihasilkan oleh perlakuan yang diberi cacing sutera saja, akan tetapi bila dihitung dari hasil penjualan akhir dengan hasil sintasan yang diperoleh dari penelitian, margin terbesar diperoleh dari perlakuan $\mathrm{C}$.

\section{KESIMPULAN}

Berdasarkan hasil penelitian, substitusi pakan alami oleh pakan buatan yang ditambah probiotik memberikan pengaruh yang nyata terhadap performa tumbuh larva Ikan Lele. Parameter yang berpengaruh nyata adalah panjang rataan dan kelangsungan hidup larva. Secara keseluruhan kinerja pertumbuhan, perlakuan terbaik ditunjukkan oleh perlakuan C (substitusi pakan alami oleh pakan buatan+probiotik 50\%). Pada perlakuan ini diperoleh kelangsungan hidup larva tertinggi dengan pertumbuhan yang lebih baik daripada perlakuan kontrol (pemberian pakan cacing sutera 100\%).

\section{DAFTAR PUSTAKA}

Anggraini, RS. 2014. Kombinasi Cacing Sutra Tubifex dan Pakan Buatan pada Pemeliharaan Larva Ikan Patin Pangasius sp. Bogor : Institut Pertanian Bogor.

Anggrainy L. 2015. Kombinasi Cacing Sutra dan Pakan Buatan yang Ditambah Probiotik pada pemeliharaan Larva Ikan Lele Clarias sp. Bogor : Institut pertanian Bogor.

Aslamsyah S, Aziz HY, Sriwulan, Wiryawan KG. 2009. Mikroflora Saluran Pencernaan Ikan Gurame. Torani (Jurnal Ilmu Kelautan dan Perikanan) 19(1): 66-73

Fajri NW, Hutabarat J. 2014. Pengaruh Penambahan Kotoran Ayam, Ampas Tahu dan Tepung Tapioka dalam media Kultur terhadap Biomassa, Populasi, dan Kandungan Nutrisi Cacing Sutra (Tubifex sp.). Journal of Aquaculture Management and Technology 3(4): 101-108.

Halver JE. 1989. Fish Nutrition. Second edition. New York: Academic Press Inc.

Kamler E. 1992. Early Life History of Fish: an Energetics Approach. First Edition. London: Chapman \& Hall.

Mayasari N. 2012. Pemacuan kematangan gonad ikan Lele dumbo Clarias sp. betina dengan kombinasi hormon PMSG dan Spirulina [tesis]. Bogor (ID): Institut Pertanian Bogor.

Nurhayati. 2014.Evaluasi Pemberian Kombinasi Cacing Sutra dan Pakan Buatan terhadap Perkembangan Organ dan Enzim Pencernaan Untuk Pertumbuhan Larva Ikan Lele Dumbo (Clarias sp.). Bogor : Institut Pertanian Bogor.

Subandiyono N dan Elfitra T. 2013. Pengaruh Penggunaan Bromelin Terhadap Tingkat Pemanfaatan Protein Pakan dan Pertumbuhan Lele Dumbo (Clarias gariepinus). Journal of Aquaculture Management and Technology 2(2):57-63. 
Takeuchi T. 1988. Laboratory Work Chemical Evaluation ofDietary Nutrition. In Watanabe T, ed. Fish Nutrition and Mariculture, JICA Textbook the General Aquaculture Course. Tokyo : Kanagawa Internat. Hlm: 179-229.

Yuliantini RR. 2015. Evaluais Pemberian Artemia yang Diperkaya Sumber Asam LemakEsensial terhadap Kinerja Produksi Larva Ikan lele. Bogor: Institut Pertanian Bogor.

Verschuler L, Rombaut G, Sorgeloos P, Vertreate W. 2000. Probiotic Bacteria as Biological Control Agent in Aquaculture. Microbiology and Molecular Biology 64(4): 655-671. 